\title{
Article \\ Hydrogen Sulfide Reduces Ischemia and Reperfusion Injury in Neuronal Cells in a Dose- and Time-Dependent Manner
}

\author{
Stefanie Scheid ${ }^{1}$, Max Goeller ${ }^{1}$, Wolfgang Baar ${ }^{1}$, Jakob Wollborn ${ }^{1,2}{ }^{\oplus}$, Hartmut Buerkle ${ }^{1}$, Günther Schlunck ${ }^{3}$, \\ Wolf Lagrèze ${ }^{3}$, Ulrich Goebel ${ }^{4}$ (i) and Felix Ulbrich ${ }^{1, *}$ \\ 1 Department of Anesthesiology and Critical Care, Medical Center-University of Freiburg, Faculty of Medicine, \\ University of Freiburg, 79106 Freiburg, Germany; stefanie.scheid@uniklinik-freiburg.de (S.S.); \\ max.goeller@uniklinik-freiburg.de (M.G.); wolfgang.baar@uniklinik-freiburg.de (W.B.); \\ jwollborn@bwh.harvard.edu (J.W.); hartmut.buerkle@uniklinik-freiburg.de (H.B.) \\ 2 Department of Anesthesiology, Perioperative and Pain Medicine, Brigham and Woman's Hospital, \\ Harvard Medical School, Boston, MA 02115, USA \\ 3 Eye-Center, Medical Center-University of Freiburg, Faculty of Medicine, University of Freiburg, \\ 79106 Freiburg, Germany; guenther.schlunck@uniklinik-freiburg.de (G.S.); \\ wolf.lagreze@uniklinik-freiburg.de (W.L.) \\ 4 Department of Anesthesiology and Critical Care Medicine, St. Franziskus-Hospital, \\ 48145 Muenster, Germany; ulrich.goebel@uniklinik-freiburg.de \\ * Correspondence: felix.ulbrich@uniklinik-freiburg.de
}

check for updates

Citation: Scheid, S.; Goeller, M.; Baar, W.; Wollborn, J.; Buerkle, H.; Schlunck, G.; Lagrèze, W.; Goebel, U.; Ulbrich, F. Hydrogen Sulfide Reduces Ischemia and Reperfusion Injury in Neuronal Cells in a Dose- and Time-Dependent Manner. Int. J. Mol. Sci. 2021, 22, 10099. https://doi.org/ 10.3390/ijms221810099

Academic Editor: Carla Cicala

Received: 18 August 2021

Accepted: 16 September 2021

Published: 18 September 2021

Publisher's Note: MDPI stays neutral with regard to jurisdictional claims in published maps and institutional affiliations.

Copyright: (c) 2021 by the authors Licensee MDPI, Basel, Switzerland. This article is an open access article distributed under the terms and conditions of the Creative Commons Attribution (CC BY) license (https:// creativecommons.org/licenses/by/ $4.0 /)$.

\begin{abstract}
Background: The ischemia-reperfusion injury (IRI) of neuronal tissue, such as the brain and retina, leads to possible cell death and loss of function. Current treatment options are limited, but preliminary observations suggest a protective effect of hydrogen sulfide $\left(\mathrm{H}_{2} \mathrm{~S}\right)$. However, the dosage, timing, and mechanism of inhaled $\mathrm{H}_{2} \mathrm{~S}$ treatment after IRI requires further exploration. Methods: We investigated possible neuroprotective effects of inhaled $\mathrm{H}_{2} \mathrm{~S}$ by inducing retinal ischemia-reperfusion injury in rats for the duration of $1 \mathrm{~h}(120 \mathrm{mmHg})$, followed by the administration of hydrogen sulfide $\left(\mathrm{H}_{2} \mathrm{~S}\right)$ for $1 \mathrm{~h}$ at different time points $(0,1.5$, and $3 \mathrm{~h}$ after the initiation of reperfusion) and at different $\mathrm{H}_{2} \mathrm{~S}$ concentrations $(120,80$, and $40 \mathrm{ppm})$. We quantified the $\mathrm{H}_{2} \mathrm{~S}$ effect by conducting retinal ganglion cell counts in fluorogold-labeled animals 7 days after IRI. The retinal tissue was harvested after $24 \mathrm{~h}$ for molecular analysis, including qPCR and Western blotting. Apoptotic and inflammatory mediators, transcription factors, and markers for oxidative stress were investigated. Histological analyses of the retina and the detection of inflammatory cytokines in serum assays were also performed. Results: The effects of inhaled $\mathrm{H}_{2} \mathrm{~S}$ were most evident at a concentration of $80 \mathrm{ppm}$ administered $1.5 \mathrm{~h}$ after IRI. $\mathrm{H}_{2} \mathrm{~S}$ treatment increased the expression of anti-apoptotic Bcl-2, decreased pro-apoptotic Bax expression, reduced the release of the inflammatory cytokines IL- $1 \beta$ and TNF- $\alpha$, attenuated NF- $\mathrm{KB}$ p65, and enhanced Akt phosphorylation. $\mathrm{H}_{2} \mathrm{~S}$ also downregulated NOX4 and cystathionine $\beta$-synthase. Histological analyses illustrated a reduction in TNF- $\alpha$ in retinal ganglion cells and lower serum levels of TNF- $\alpha$ in $\mathrm{H}_{2}$ S-treated animals after IRI. Conclusion: After neuronal IRI, $\mathrm{H}_{2} \mathrm{~S}$ mediates neuroprotection in a time- and dose-dependent manner. The $\mathrm{H}_{2} \mathrm{~S}$ treatment modulated transcription factor NF- $\mathrm{B}$ activation and reduced retinal inflammation.
\end{abstract}

Keywords: hydrogen sulfide; $\mathrm{H}_{2} \mathrm{~S}$; ischemia-reperfusion injury; neuroprotection; retinal ganglion cells

\section{Introduction}

Diseases associated with ischemia-reperfusion injury (IRI) of the central nervous system lead to neuronal cell death. Well-known examples of this disease group are traumatic brain injury and stroke, but diseases of the eye, such as retinal vascular occlusion, diabetic retinopathy, and glaucoma, are also associated with IRI. The retinal ganglion cells are very vulnerable to ischemia and have little potential for regeneration following injury. As in other neuronal cells, the IRI of retinal ganglion cells activates several apoptotic and inflammatory signaling pathways that ultimately trigger cell death [1]. 
A possible treatment that could suppress this inevitable neuronal cell death is the exposure to hydrogen sulfide $\left(\mathrm{H}_{2} \mathrm{~S}\right)$. Although $\mathrm{H}_{2} \mathrm{~S}$ is traditionally considered a toxic gas, it also functions as a natural endogenous gasotransmitter in normal physiological processes. It plays an important functional role in the central nervous system, where it appears to be predominantly synthesized by the enzyme cystathionine beta-synthase (CBS), which has been localized in astrocytes, as well as in microglia and neurons [2,3]. $\mathrm{H}_{2} \mathrm{~S}$ is normally stored as bound sulfane sulfur and is released by excitatory stimulation [4]. Elevated levels of endogenously produced $\mathrm{H}_{2} \mathrm{~S}$ are detected after middle cerebral artery occlusion and may contribute to the pathology of stroke [5].

At low doses, exogenously applied $\mathrm{H}_{2} \mathrm{~S}$ may be beneficial in pathophysiological processes. Several in vitro and in vivo studies have demonstrated that $\mathrm{H}_{2} \mathrm{~S}$ may contribute to neuroprotective effects. This is likely mediated through a variety of mechanisms, including vasodilatation via the activation of potassium-dependent ATP channels [6], direct endothelial vasorelaxation [7], antioxidation by radical scavenging [8], interference with intracellular signal transduction, and a consecutive reduction in inflammation $[9,10]$. However, at high concentrations, $\mathrm{H}_{2} \mathrm{~S}$ causes toxic effects, probably by inhibiting cytochrome $\mathrm{c}$ oxidase and blocking aerobic ATP generation, leading to subsequent cell death [11].

Only a few studies have examined the use of inhaled $\mathrm{H}_{2} \mathrm{~S}$ as a treatment for neuronal injury. Geng et al. investigated the impact of inhaled $\mathrm{H}_{2} \mathrm{~S}$ after cardiac arrest and cardiopulmonary resuscitation in rats. The application of $80 \mathrm{ppm} \mathrm{H}_{2} \mathrm{~S}$ immediately after injury reduced the permeability of the blood-brain barrier, decreased brain edema, attenuated neurological dysfunction, and increased survival [12]. Li et al. also used a cardiac arrest and resuscitation model to confirm the protective effects of $\mathrm{H}_{2} \mathrm{~S}$ and showed similar anti-inflammatory potency of both 80 and $40 \mathrm{ppm} \mathrm{H}_{2} \mathrm{~S}$ [13]. Evidence of an $\mathrm{H}_{2} \mathrm{~S}$-associated neuroprotection of neuronal cells in the eye was shown by Biermann et al., who demonstrated that $80 \mathrm{ppm} \mathrm{H}_{2} \mathrm{~S}$ administered immediately before IRI decreased retinal ganglion cell death and reduced retinal inflammation [14].

To our knowledge, the effects of various concentrations of $\mathrm{H}_{2} \mathrm{~S}$ administered at different time points after neuronal IRI have not been studied so far. Therefore, we performed investigations in a rat model of retinal IRI to determine the most effective inhaled $\mathrm{H}_{2} \mathrm{~S}$ treatment as indicated by various apoptotic and inflammatory markers.

\section{Results}

\section{1. $\mathrm{H}_{2} \mathrm{~S}$ Inhalation Protects Retinal Ganglion Cells from IRI-Induced Apoptosis at Specific Concentrations and Times}

IRI induced a loss of approximately $50 \%$ of the retinal ganglion cells (IRI: $1540 \pm 78$ vs. untreated: $2592 \pm 54$; Figure 1, Col. 1 and 2). Inhaled $\mathrm{H}_{2} \mathrm{~S}$ was able to attenuate this effect at concentrations of 120 and $80 \mathrm{ppm}$ at specific time points (Figure 1, Col 4, 6, 7). At a concentration of $120 \mathrm{ppm}$, only the inhalation administered at $1.5 \mathrm{~h}$ after IRI had a protective effect, as indicated by a significantly reduced cell death (IRI $+120 \mathrm{ppm}_{2} \mathrm{~S}$ at $1.5 \mathrm{~h}: 2039 \pm 99, p<0.001$ ). The immediate inhalation (time point of $0 \mathrm{~h}$ ), or inhalation after a time delay of $3 \mathrm{~h}$, had no protective benefit (IRI $+120 \mathrm{ppm} \mathrm{H}_{2} \mathrm{~S}$ at $0 \mathrm{~h}: 1540 \pm 78$; $\mathrm{IRI}+120 \mathrm{ppm} \mathrm{H}_{2} \mathrm{~S}$ at $3 \mathrm{~h}$ : $1686 \pm 105$ ). The administration of $80 \mathrm{ppm}_{2} \mathrm{~S}$ had a strong protective effect at two time points $(0$ and $1.5 \mathrm{~h})$, with the best results occurring after inhalation with a $1.5 \mathrm{~h}$ delay (IRI $+80 \mathrm{ppm}_{2} \mathrm{~S}$ at $0 \mathrm{~h}$ : $2039 \pm 99$ and IRI $+80 \mathrm{ppm}_{2} \mathrm{~S}$ at 1.5 h: $2234 \pm 181$; both $p<0.001$ ). However, no protection against cell death was observed after a time delay of $3 \mathrm{~h}$ following IRI. The administration of $40 \mathrm{ppm}_{2} \mathrm{~S}$ also failed to prevent retinal ganglion cell death at any time point after IRI (IRI $+40 \mathrm{ppm}_{2} \mathrm{~S}$ at $0 \mathrm{~h}$ : $1702 \pm 140 ; \mathrm{IRI}+40$ ppm $\mathrm{H}_{2} \mathrm{~S}$ at 1.5 h: $1671 \pm 92 ; \mathrm{IRI}+40$ ppm $\mathrm{H}_{2} \mathrm{~S}$ at 3 h: $1569 \pm 103$ ). Representative images of vital retinal ganglion cells and the induction of cell death by IRI, as well as the protective effects of hydrogen sulfide, are shown in Figure 2. 


\section{2. $\mathrm{H}_{2} \mathrm{~S}$ Inhalation Reduced Bax Expression and Increased Bcl-2 Expression}

$\mathrm{H}_{2} \mathrm{~S}$ also affected the expression of pro-apoptotic Bax and anti-apoptotic Bcl-2 after IRI (Figure 3). The strongest effect in each case was observed for the $80 \mathrm{ppm}$ treatment applied with a delay of $1.5 \mathrm{~h}$ (Bax-IRI: $1.84 \pm 0.06 \mathrm{vs}$. IRI $+80 \mathrm{ppm} \mathrm{H}_{2} \mathrm{~S}$ at $1.5 \mathrm{~h}$ :

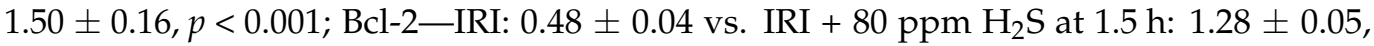
$p<0.001)$. However, the immediate application of $80 \mathrm{ppm}_{2} \mathrm{~S}$ also significantly reduced Bax and increased Bcl-2 expression (Bax-IRI: $1.84 \pm 0.06$ vs. IRI $+80 \mathrm{ppm}_{2} \mathrm{~S}$ at $0 \mathrm{~h}$ : $1.60 \pm 0.12, p<0.01$; Bcl-2-IRI: $0.48 \pm 0.04$ vs. IRI +80 ppm $\mathrm{H}_{2} \mathrm{~S}$ at 0 h: $1.22 \pm 0.04$, $p<0.001)$. By contrast, the effect was attenuated but still statistically significant following treatment with $120 \mathrm{ppm} \mathrm{H}_{2} \mathrm{~S}$ with a delay of $1.5 \mathrm{~h}$ (Bax-IRI: $1.84 \pm 0.06 \mathrm{vs}$. IRI $+120 \mathrm{ppm}$

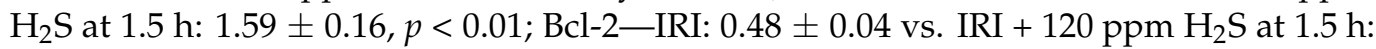
$1.14 \pm 0.07, p<0.001$ ), whereas the immediate application of $120 \mathrm{ppm}_{2} \mathrm{~S}$ had no effect. A delay of $3 \mathrm{~h}$, as well as treatment with $40 \mathrm{ppm} \mathrm{H}_{2} \mathrm{~S}$, had no influence on Bax or Bcl-2 expression.

\section{3. $\mathrm{H}_{2} \mathrm{~S}$ Inhalation Reduced NOX4 Expression}

$\mathrm{H}_{2} \mathrm{~S}$ treatment inhibited the expression of NOX4, a member of the NADPH oxygenase family that is critically involved in the production of reactive oxygen species (Figure 4). The most potent treatment was $80 \mathrm{ppm}$ with a $1.5 \mathrm{~h}$ delay (IRI: $1.58 \pm 0.08$ vs. IRI $+80 \mathrm{ppm} \mathrm{H}_{2} \mathrm{~S}$ at 1.5 h: $0.51 \pm 0.08, p<0.001$, IRI $+80 \mathrm{ppm} \mathrm{H}_{2} \mathrm{~S}$ at $0 \mathrm{~h}: 0.73 \pm 0.10, p<0.001 ; \mathrm{IRI}+120 \mathrm{ppm}$ $\mathrm{H}_{2} \mathrm{~S}$ at $\left.1.5 \mathrm{~h}: 0.75 \pm 0.07, p<0.001\right)$.

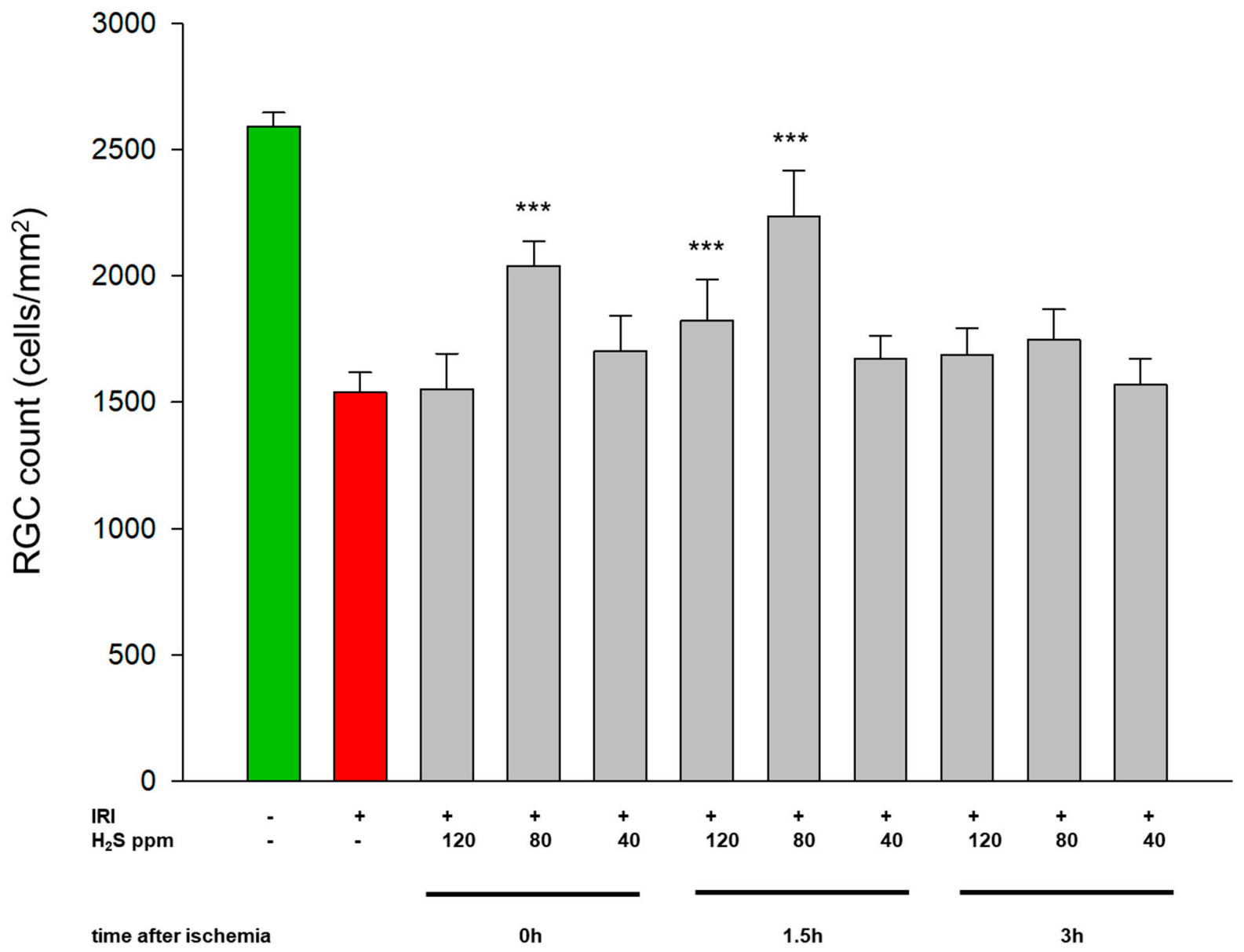

Figure 1. Time- and dose-dependent influence of $\mathrm{H}_{2} \mathrm{~S}$ inhalation on retinal ganglion cell count after ischemia-reperfusion injury (IRI). Quantification of retinal ganglion cell density (cells $/ \mathrm{mm}^{2}$, data are the mean $\pm \mathrm{SD}, n=8,{ }^{* * *}=p<0.001$; IRI vs. IRI +80 ppm $\mathrm{H}_{2} \mathrm{~S}$ at $0 \mathrm{~h}$ and $1.5 \mathrm{~h}$, vs. IRI $+120 \mathrm{ppm} \mathrm{H}_{2} \mathrm{~S}$ at $1.5 \mathrm{~h}$ ). 

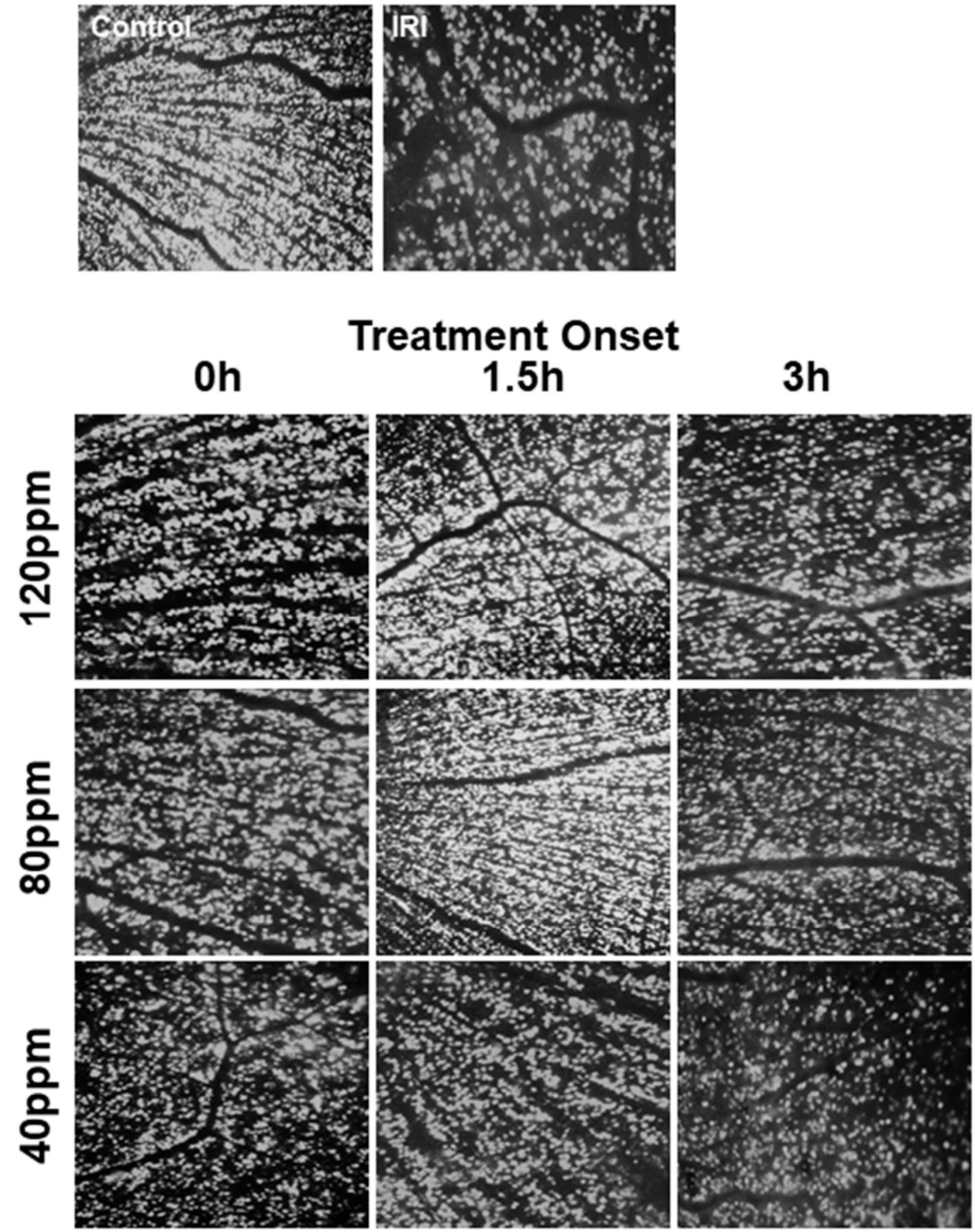

Figure 2. Time- and dose-dependent influence of $\mathrm{H}_{2} \mathrm{~S}$ inhalation on vital retinal ganglion cells after ischemia-reperfusion injury (IRI). Representative flat mount images $(n=8)$ of fluorogold-labeled retinal ganglion cells 7 days after IRI and immediate $(0 \mathrm{~h})$ and delayed (i.e., 1.5 and $3 \mathrm{~h}) \mathrm{H}_{2} \mathrm{~S}$ inhalation (40, 80 and $\left.120 \mathrm{ppm}\right)$. 


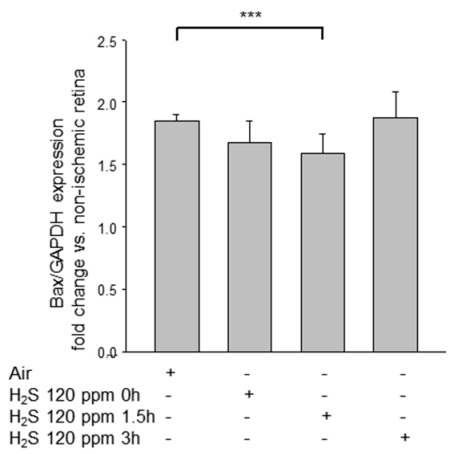

(a)

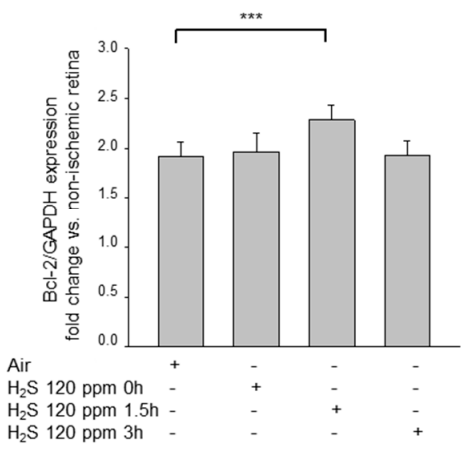

(d)

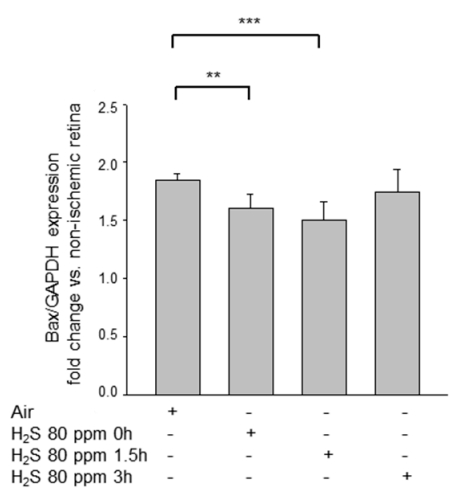

(b)

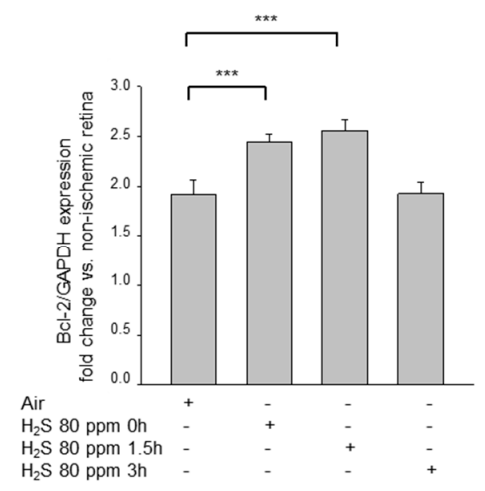

(e)

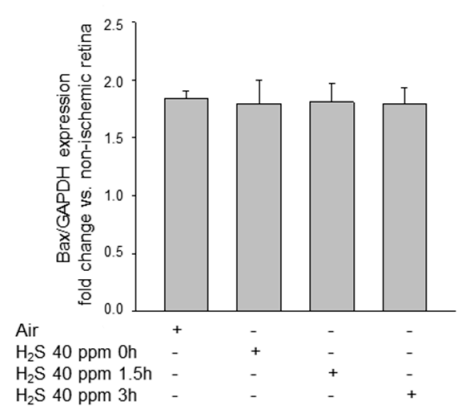

(c)

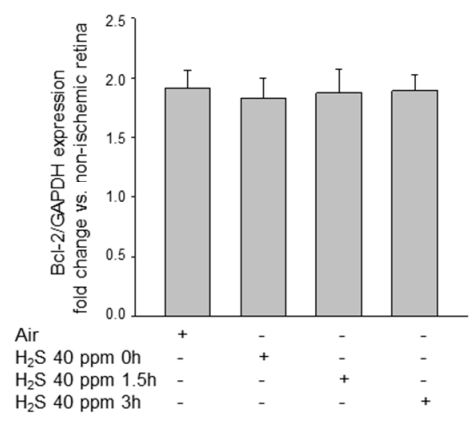

(f)

Figure 3. Effect of $\mathrm{H}_{2} \mathrm{~S}$ inhalation on retinal expression of Bax and Bcl-2 mRNA. (a-c) Fold induction of Bax mRNA expression in ischemic retinal tissue compared to GAPDH in relation to the corresponding non-ischemic retinae analyzed by RT-PCR after (a) 120 ppm $\mathrm{H}_{2} \mathrm{~S}$ inhalation (data are mean $\pm \mathrm{SD}, n=8$; ** $=p<0.01$, IRI vs. $120 \mathrm{ppm} \mathrm{H}_{2} \mathrm{~S}$ at $1.5 \mathrm{~h}$ ), (b) 80 ppm $\mathrm{H}_{2} \mathrm{~S}$ inhalation (data are mean $\pm \mathrm{SD}, n=8$; ${ }^{* * *}=p<0.001$, IRI vs. IRI $+80 \mathrm{ppm} \mathrm{H}_{2} \mathrm{~S}$ at $1.5 \mathrm{~h}$; ${ }^{* *}=p<0.01$, IRI vs. IRI +80 ppm $\mathrm{H}_{2} \mathrm{~S}$ at $0 \mathrm{~h}$ ), and (c) 40 ppm $\mathrm{H}_{2} \mathrm{~S}$ inhalation. (d-f) Fold induction of Bcl-2 mRNA expression in ischemic retinal tissue compared to GAPDH in relation to the corresponding non-ischemic retinae analyzed by RT-PCR after (d) 120 ppm $\mathrm{H}_{2} \mathrm{~S}$ inhalation (data are mean $\pm \mathrm{SD}, n=8$; ${ }^{* * *}=p<0.001$, IRI vs. $120 \mathrm{ppm} \mathrm{H}_{2} \mathrm{~S}$ at $1.5 \mathrm{~h}$ ), (e) $80 \mathrm{ppm} \mathrm{H}_{2} \mathrm{~S}$ inhalation (data are mean $\pm \mathrm{SD}, n=8 ;^{* * *}=p<0.001$, IRI vs. IRI $+80 \mathrm{ppm} \mathrm{H}_{2} \mathrm{~S}$ at $1.5 \mathrm{~h} ;{ }^{* *}=p<0.001$, IRI vs. IRI $+80 \mathrm{ppm} \mathrm{H}_{2} \mathrm{~S}$ at $\left.0 \mathrm{~h}\right)$ and (f) 40 ppm $\mathrm{H}_{2} \mathrm{~S}$ inhalation.

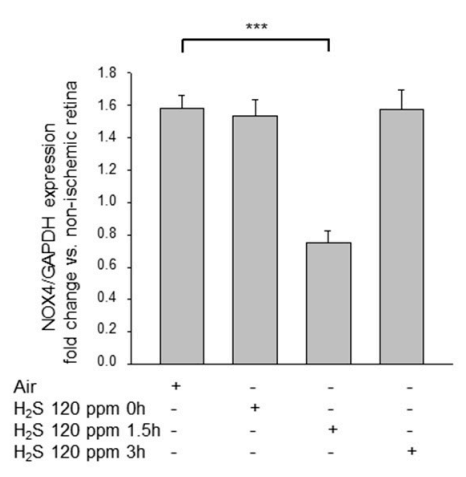

(a)

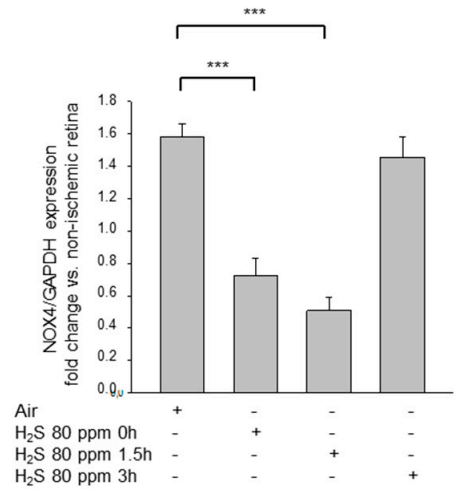

(b)

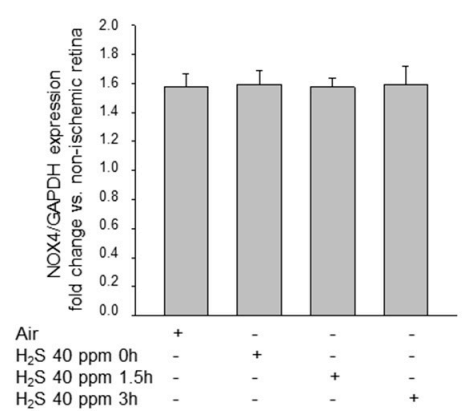

(c)

Figure 4. Effect of $\mathrm{H}_{2} \mathrm{~S}$ inhalation on retinal expression of NOX-4 mRNA. Fold induction of NOX-4 mRNA expression in ischemic retinal tissue compared to GAPDH in relation to the corresponding non-ischemic retinae analyzed by RT-PCR after (a) $120 \mathrm{ppm} \mathrm{H}_{2} \mathrm{~S}$ inhalation (data are mean $\pm \mathrm{SD}, n=8$; ${ }^{* * *}=p<0.001$, IRI vs. $120 \mathrm{ppm} \mathrm{H}_{2} \mathrm{~S}$ at $1.5 \mathrm{~h}$ ), (b) $80 \mathrm{ppm} \mathrm{H} \mathrm{H}_{2} \mathrm{~S}$ inhalation (data are mean $\pm \mathrm{SD}, n=8 ;^{* * *}=p<0.001$, IRI vs. IRI $+80 \mathrm{ppm}_{2} \mathrm{~S}$ at $0 \mathrm{~h}$ and vs. IRI $+80 \mathrm{ppm} \mathrm{H}_{2} \mathrm{~S}$ at $1.5 \mathrm{~h}$ ), and (c) 40 ppm $\mathrm{H}_{2} \mathrm{~S}$ inhalation. 


\section{4. $\mathrm{H}_{2} \mathrm{~S}$ Inhalation Decreased Inflammatory Cytokine Expression}

$\mathrm{H}_{2} \mathrm{~S}$ treatment decreased the pro-inflammatory cytokine response, as indicated by the decreased expression of the inflammatory cytokines IL- $1 \beta$ and TNF- $\alpha$, as determined by qPCR (Figure 5). The extent of the downregulation depended on the specific concentration and timing of the $\mathrm{H}_{2} \mathrm{~S}$ treatment. Significant changes were noted at $80 \mathrm{ppm}$ at $1.5 \mathrm{~h}$ and $0 \mathrm{~h}$, and at 120 ppm at $1.5 \mathrm{~h}$ (IL-1ß-IRI: $2.12 \pm 0.24$ vs. IRI $+80 \mathrm{ppm} \mathrm{H}_{2} \mathrm{~S}$ at $1.5 \mathrm{~h}: 0.64 \pm 0.12$, $p<0.001 ; \mathrm{IRI}+80 \mathrm{ppm} \mathrm{H}_{2} \mathrm{~S}$ at 0 h: $1.33 \pm 0.10, p<0.001 ; \mathrm{IRI}+120 \mathrm{ppm} \mathrm{H}_{2} \mathrm{~S}$ at $1.5 \mathrm{~h}$ : $1.14 \pm 0.13, p<0.01$; TNF- $\alpha$-IRI: $1.52 \pm 0.15$ vs. IRI +80 ppm $\mathrm{H}_{2} \mathrm{~S}$ at $1.5 \mathrm{~h}: 1.15 \pm 0.13$,

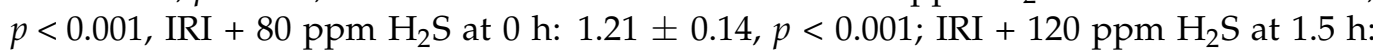
$1.23 \pm 0.15, p<0.01)$. Treatment at the other time points, as well as the $40 \mathrm{ppm}_{2} \mathrm{~S}$ treatment, had no effect on cytokine expression.

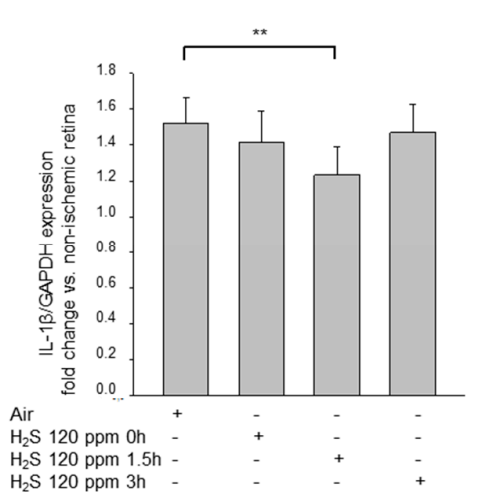

(a)

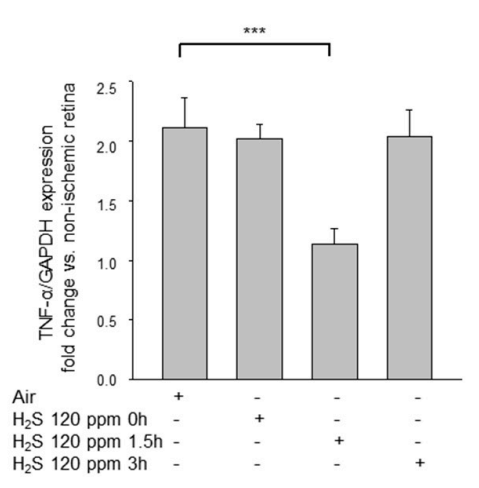

(d)

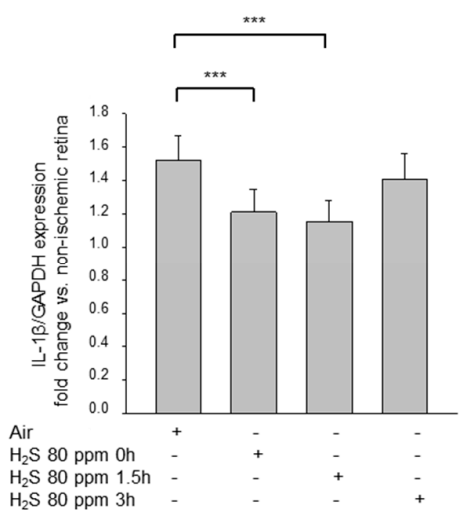

(b)

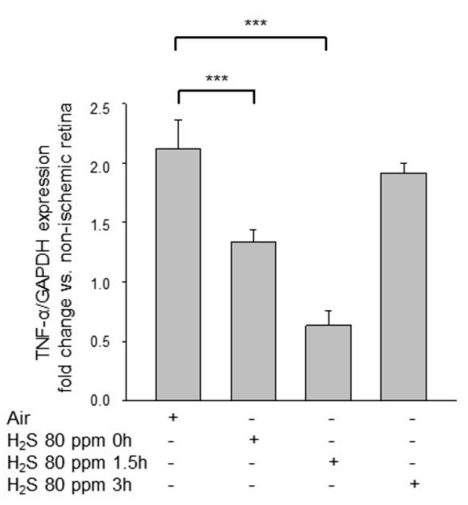

(e)

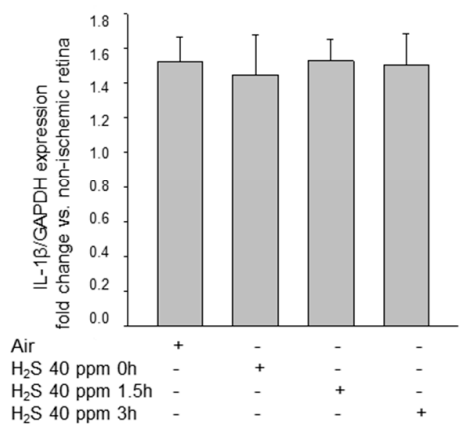

(c)

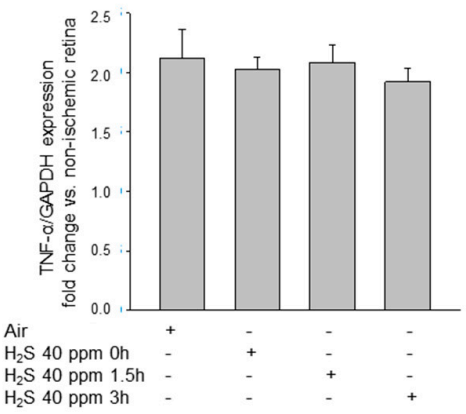

(f)

Figure 5. Effect of $\mathrm{H}_{2} \mathrm{~S}$ inhalation on the retinal expression of IL-1ß and TNF- $\alpha$ mRNA. (a-c) Fold induction of IL- $1 ß$ mRNA expression in ischemic retinal tissue compared to GAPDH in relation to the corresponding non-ischemic retinae analyzed by RT-PCR after (a) 120 ppm $\mathrm{H}_{2} \mathrm{~S}$ inhalation (data are mean $\pm \mathrm{SD}, n=8$; ** $=p \leq 0.01$, IRI vs. 120 ppm $\mathrm{H}_{2} \mathrm{~S}$ at $1.5 \mathrm{~h}$ ), (b) $80 \mathrm{ppm}$ $\mathrm{H}_{2} \mathrm{~S}$ inhalation (data are mean $\pm \mathrm{SD}, n=8 ;{ }^{* * *}=p<0.001 \mathrm{IRI}$ vs. IRI $+80 \mathrm{ppm} \mathrm{H}_{2} \mathrm{~S}$ at $0 \mathrm{~h}$ and vs. IRI $+80 \mathrm{ppm} \mathrm{H}_{2} \mathrm{~S}$ at $1.5 \mathrm{~h}$ ), and (c) 40 ppm $\mathrm{H}_{2} \mathrm{~S}$ inhalation. (d-f) Fold induction of TNF- $\alpha$ mRNA expression in ischemic retinal tissue compared to GAPDH in relation to the corresponding non-ischemic retinae analyzed by RT-PCR after (d) 120 ppm $\mathrm{H}_{2} \mathrm{~S}$ inhalation (data are mean $\pm \mathrm{SD}, n=8 ;{ }^{* *}=p<0.001$, IRI vs. $120 \mathrm{ppm} \mathrm{H}_{2} \mathrm{~S}$ at $1.5 \mathrm{~h}$ ), (e) $80 \mathrm{ppm} \mathrm{H}_{2} \mathrm{~S}$ inhalation (data are mean $\pm \mathrm{SD}, n=8$; *** $=p<0.001$, IRI vs. IRI $+80 \mathrm{ppm} \mathrm{H}_{2} \mathrm{~S}$ at $0 \mathrm{~h}$ and vs. IRI $+80 \mathrm{ppm} \mathrm{H}_{2} \mathrm{~S}$ at $1.5 \mathrm{~h}$ ), and (f) $40 \mathrm{ppm} \mathrm{H}_{2} \mathrm{~S}$ inhalation.

\section{5. $\mathrm{H}_{2} \mathrm{~S}$ Inhalation Inhibits TNF- $\alpha$ Expression in the Ganglion Cell Layer}

The cytokine TNF- $\alpha$ is a key regulator of the inflammatory response among others. $\mathrm{TNF}-\alpha$ was detected mainly in the inner nuclear layer and the area of the ganglion cell layer in retinal cross-sections of IRI eyes (Figure 6). $\mathrm{H}_{2} \mathrm{~S}$ treatment (80 ppm, time interval $1.5 \mathrm{~h}$ ) resulted in weaker staining, indicating decreased TNF- $\alpha$ expression. 

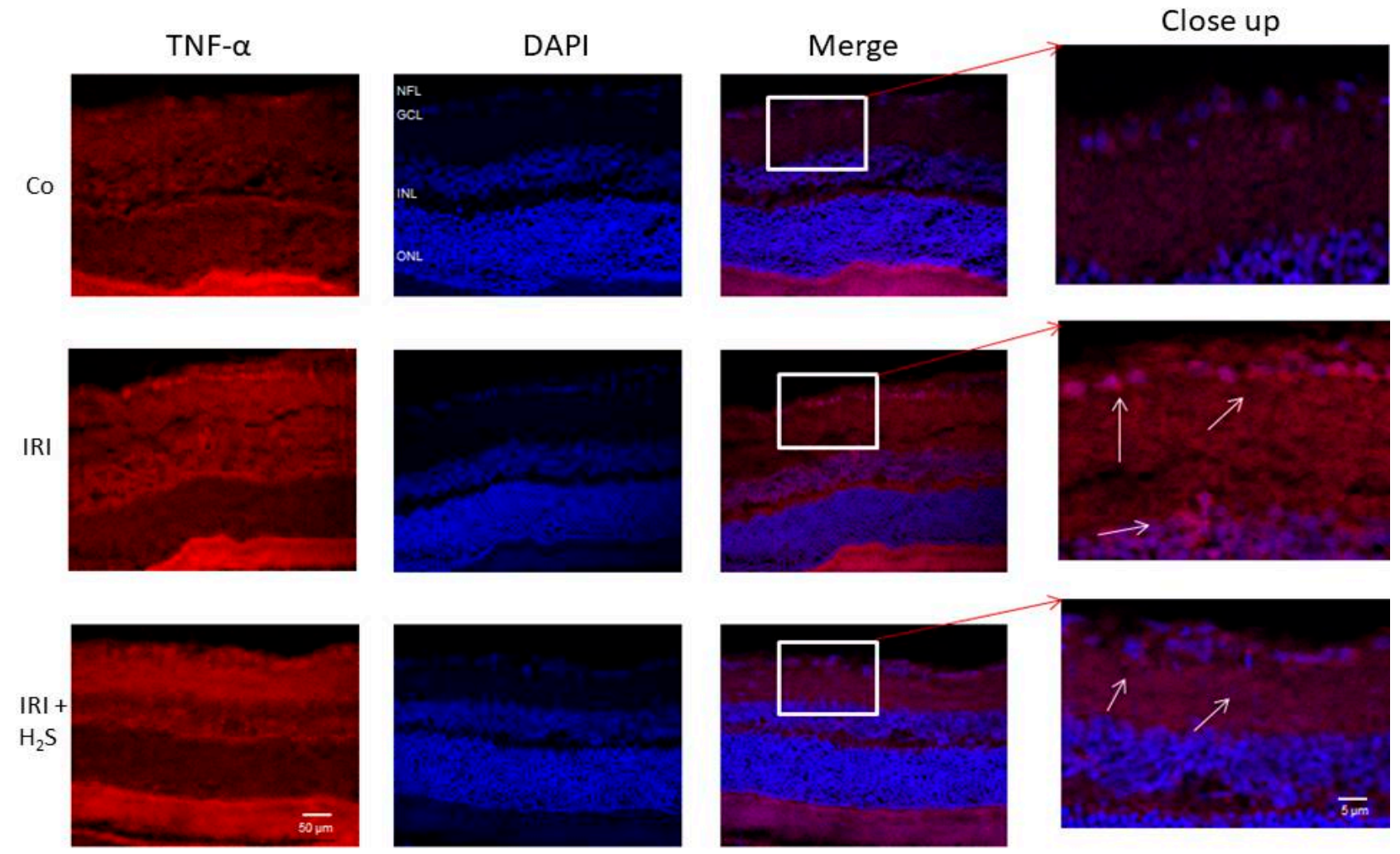

Figure 6. TNF- $\alpha$ expression after unilateral IRI and $\mathrm{H}_{2} \mathrm{~S}$ inhalation. Double staining was performed to clarify in which areas of the retina the expression of TNF- $\alpha$ occurs. Cross-sections of the retinae 7 days after unilateral IRI showed that IRI led to an increased expression of TNF- $\alpha$ mainly in the retinal ganglion cell layer, as well as in the inner nuclear layer. After the application of $\mathrm{H}_{2} \mathrm{~S}$, the expression was attenuated. Abbreviations: NFL = nerve fiber layer; GCL = ganglion cell layer; $\mathrm{INL}=$ inner nuclear layer; ONL = outer nuclear layer.

\section{6. $\mathrm{H}_{2} \mathrm{~S}$ Inhalation Attenuates Inflammatory Cytokine Expression in Peripheral Blood}

$\mathrm{H}_{2} \mathrm{~S}$ treatment decreased TNF- $\alpha$ levels in the peripheral blood when compared to room air treatment after retinal IRI (IRI: $95 \pm 20 \mathrm{pg} / \mu \mathrm{L}$; Figure $7 \mathrm{~b}$ ). However, the decrease was not statistically significant after immediate treatment or after treatment with a delay of $3 \mathrm{~h}$ (IRI $+80 \mathrm{ppm} \mathrm{H}_{2} \mathrm{~S}$ at $0 \mathrm{~h}: 79 \pm 8 \mathrm{pg} / \mu \mathrm{L}$; IRI $+80 \mathrm{ppm} \mathrm{H}_{2} \mathrm{~S}$ at $3 \mathrm{h:} 81 \pm 8 \mathrm{pg} / \mu \mathrm{L}$ ). A more pronounced effect was detected when the $\mathrm{H}_{2} \mathrm{~S}$ treatment was given at $1.5 \mathrm{~h}$ after IRI (IRI $+80 \mathrm{ppm} \mathrm{H}_{2} \mathrm{~S}$ at $1.5 \mathrm{~h}: 68 \pm 8 \mathrm{pg} / \mu \mathrm{L}, p<0.05$ ). In contrast to TNF- $\alpha$, only a slight decrease in IL-1 $\beta$ was detectable in serum after immediate and delayed $(1.5 \mathrm{~h}) \mathrm{H}_{2} \mathrm{~S}$ administration, which was not significant (Figure 7a; IRI: $53 \pm 8 \mathrm{pg} / \mu \mathrm{L}$ vs. IRI $+80 \mathrm{ppm}$ $\mathrm{H}_{2} \mathrm{~S}$ at $0 \mathrm{~h}: 47 \pm 8 \mathrm{pg} / \mu \mathrm{L}$ and IRI $+80 \mathrm{ppm} \mathrm{H}_{2} \mathrm{~S}$ at $\left.1.5 \mathrm{~h}: 47 \pm 4 \mathrm{pg} / \mu \mathrm{L}\right)$. With a $3 \mathrm{~h}$ delay, no difference in IL-1 $\beta$ levels was detectable (IRI: $53 \pm 8 \mathrm{pg} / \mu \mathrm{L}$ vs. IRI $+80 \mathrm{ppm}_{2} \mathrm{~S}$ at $0 \mathrm{~h}$ : $52 \pm 5 \mathrm{pg} / \mu \mathrm{L})$.

\section{7. $\mathrm{H}_{2} \mathrm{~S}$ Inhalation Decreased CBS Expression}

The endogenous production of $\mathrm{H}_{2} \mathrm{~S}$ is linked to the activity of enzymes, such as CBS. The $120 \mathrm{ppm} \mathrm{H}_{2} \mathrm{~S}$ treatment applied immediately after reperfusion showed the strongest inhibition of CBS expression (Figure 8; IRI: $1.58 \pm 0.14 \mathrm{vs}$. IRI $+120 \mathrm{ppm}_{2} \mathrm{~S}$ at 0 h:

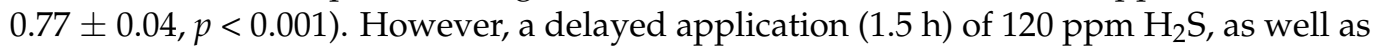
the $80 \mathrm{ppm}$ treatments at $0 \mathrm{~h}$ and $1.5 \mathrm{~h}$, also caused a significant reduction in CBS expression (IRI: $1.58 \pm 0.14$ vs. IRI $+120 \mathrm{ppm} \mathrm{H}_{2} \mathrm{~S}$ at $1.5 \mathrm{~h}: 1.11 \pm 0.18, p<0.001$; IRI $+80 \mathrm{ppm} \mathrm{H}_{2} \mathrm{~S}$ at 0 h: $1.03 \pm 0.13, p<0.001$; IRI +80 ppm $\mathrm{H}_{2} \mathrm{~S}$ at 1.5 h: $1.00 \pm 0.20, p<0.001$ ). 


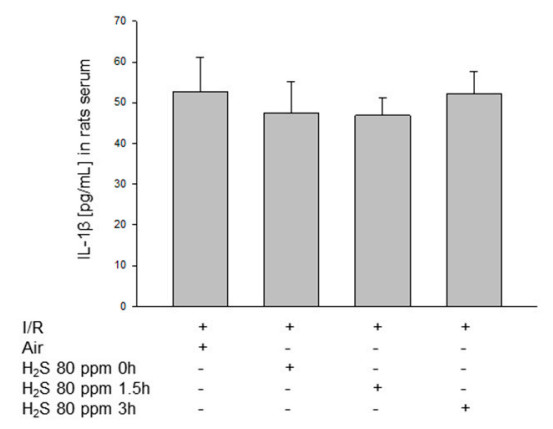

(a)

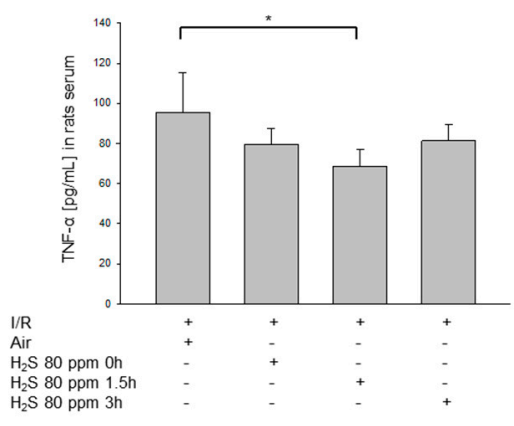

(b)

Figure 7. Effect of $\mathrm{H}_{2} \mathrm{~S}$ inhalation on IL-1 $\beta$ and TNF- $\alpha$ levels in peripheral blood samples. (a) Analysis of IL-1 $\beta$ levels after IRI and subsequent $\mathrm{H}_{2} \mathrm{~S}$ inhalation $(80 \mathrm{ppm})(\mathrm{pg} / \mathrm{mL})$. (b) Analysis of TNF- $\alpha$ levels after IRI and subsequent $\mathrm{H}_{2} \mathrm{~S}$ inhalation $(80 \mathrm{ppm})(\mathrm{pg} / \mathrm{mL}$; data are mean $\pm \mathrm{SD}$, $n=8 ;^{*}=p<0.05$, IRI vs. IRI +80 ppm $\mathrm{H}_{2} \mathrm{~S}$ at $\left.1.5 \mathrm{~h}\right)$.

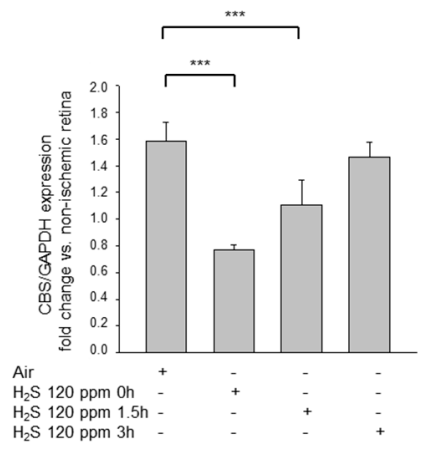

(a)

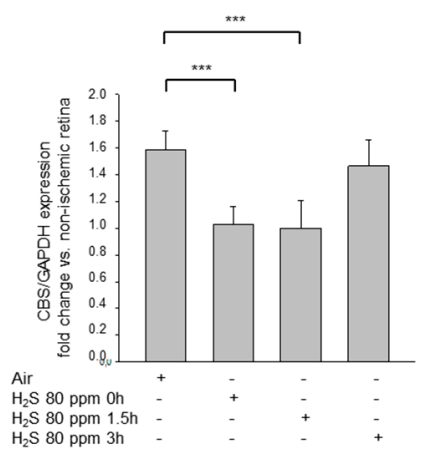

(b)

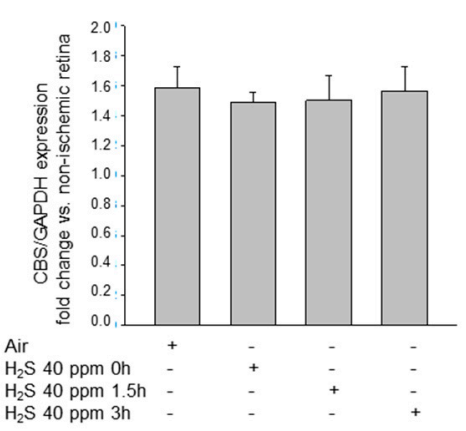

(c)

Figure 8. Effect of $\mathrm{H}_{2} \mathrm{~S}$ inhalation on the retinal expression of CBS mRNA. Fold induction of CBS mRNA expression in ischemic retinal tissue compared to GAPDH in relation to the corresponding non-ischemic retinae analyzed by RT-PCR after (a) 120 ppm $\mathrm{H}_{2} \mathrm{~S}$ inhalation (data are mean $\pm \mathrm{SD}, n=8$; ${ }^{* * *}=p<0.001$, IRI vs. $120 \mathrm{ppm} \mathrm{H}_{2} \mathrm{~S}$ at $0 \mathrm{~h}$ and vs. $120 \mathrm{ppm}$ $\mathrm{H}_{2} \mathrm{~S}$ at $1.5 \mathrm{~h}$ ), (b) $80 \mathrm{ppm} \mathrm{H}_{2} \mathrm{~S}$ inhalation (data are mean $\pm \mathrm{SD}, n=8$; ${ }^{* * *}=p<0.001$, IRI vs. IRI $+80 \mathrm{ppm} \mathrm{H}_{2} \mathrm{~S}$ at $0 \mathrm{~h}$ and vs.

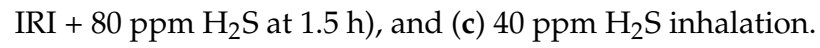

\section{8. $\mathrm{H}_{2} \mathrm{~S}$ Inhalation Reduces NF- $\kappa B$ Phosphorylation}

We also examined the activation of the transcription factor NF- $\mathrm{kB}$, which plays a critical role in inflammatory and apoptotic processes (Figure 9a). We used $80 \mathrm{ppm}$ $\mathrm{H}_{2} \mathrm{~S}$, as this showed to have the best protective effect on retinal ganglion cells. Inhalation immediately and $3 \mathrm{~h}$ after retinal IRI only slightly reduced NF- $\mathrm{kB}$ phosphorylation

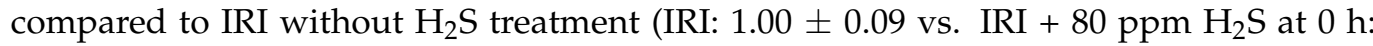
$0.90 \pm 0.10$ and IRI $+80 \mathrm{ppm} \mathrm{H}_{2} \mathrm{~S}$ at 3 h: $0.93 \pm 0.11$, n.s.). However, inhalation $1.5 \mathrm{~h}$ after IRI reduced NF-KB phosphorylation significantly (IRI: $1.00 \pm 0.09$ vs. IRI $+80 \mathrm{ppm}_{2} \mathrm{~S}$ at 1.5 h: $0.77 \pm 0.09, p<0.05)$.

\section{9. $\mathrm{H}_{2} \mathrm{~S}$ Inhalation Induced Akt Phosphorylation}

Western blot analysis showed that immediate treatment with $80 \mathrm{ppm} \mathrm{H}_{2} \mathrm{~S}$ enhanced

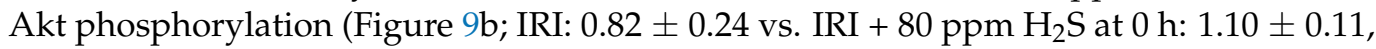
$p<0.05)$, and this effect was even more pronounced when $\mathrm{H}_{2} \mathrm{~S}$ was applied with a delay of $1.5 \mathrm{~h}$ (IRI $+80 \mathrm{ppm} \mathrm{H}_{2} \mathrm{~S}$ at $\left.1.5 \mathrm{~h}: 1.26 \pm 0.23, p<0.001\right)$. By contrast, extending the treatment delay time to $3 \mathrm{~h}$ caused only a mild and not statistically significant increase (IRI $+80 \mathrm{ppm}$ $\mathrm{H}_{2} \mathrm{~S}$ at 3 h: $0.95 \pm 0.16$, n.s.). 


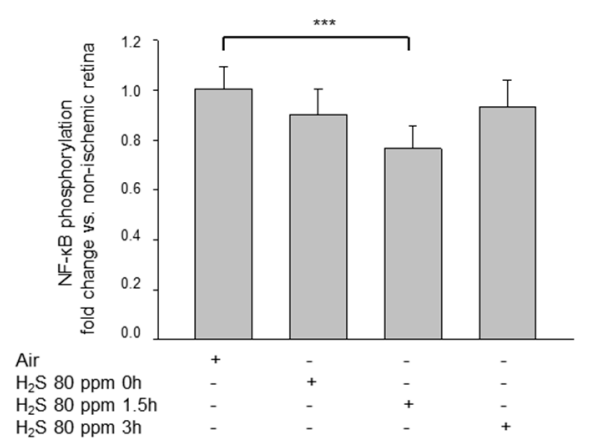

(a)

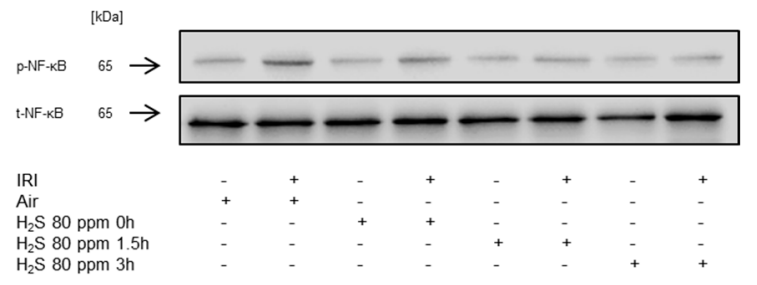

(c)

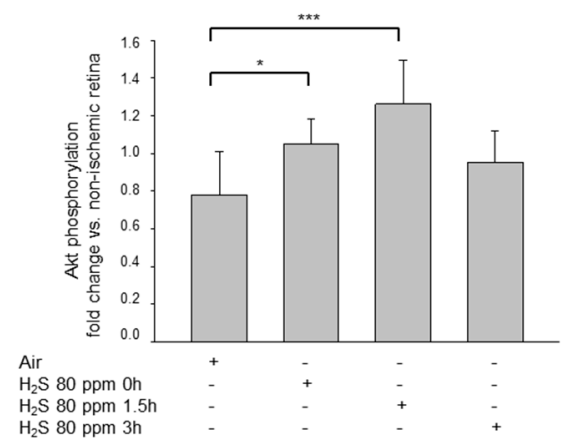

(b)

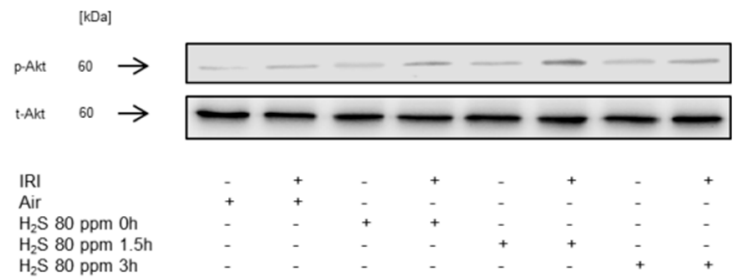

(d)

Figure 9. (a,c) Effect of $\mathrm{H}_{2} \mathrm{~S}$ inhalation on the retinal expression of NF- $\mathrm{kB}$ phosphorylation. Densitometric analysis of $n=8$ Western blots for NF- $\mathrm{kB}$ phosphorylation after time-dependent inhalation of $80 \mathrm{ppm}_{2} \mathrm{~S}$ (data are mean $\pm \mathrm{SD}, n=8$; ${ }^{* * *}=p<0.001$, IRI vs. IRI $+80 \mathrm{ppm} \mathrm{H}_{2} \mathrm{~S}$ at $\left.1.5 \mathrm{~h}\right)$ and representative Western blot image $(n=8)$ showing the suppression of retinal phosphorylation of NF- $\mathrm{kB}$ compared to total NF- $\mathrm{kB}$. (b,d) Effect of $\mathrm{H}_{2} \mathrm{~S}$ inhalation on the retinal expression of Akt phosphorylation. Densitometric analysis of $n=8$ Western blots for Akt phosphorylation after time-dependent inhalation of 80 ppm $\mathrm{H}_{2} \mathrm{~S}$ (data are mean $\pm \mathrm{SD}, n=8 ;{ }^{* *}=p<0.001$, IRI vs. IRI $+80 \mathrm{ppm} \mathrm{H}_{2} \mathrm{~S}$ at $1.5 \mathrm{~h}$, and ${ }^{*}=p<0.05$, IRI vs. IRI $+80 \mathrm{ppm} \mathrm{H}_{2} \mathrm{~S}$ at $\left.0 \mathrm{~h}\right)$ and representative Western blot image $(n=8)$ showing the increase of retinal phosphorylation of Akt compared to total Akt.

\section{Discussion}

This study investigated the neuroprotective effect of inhaled $\mathrm{H}_{2} \mathrm{~S}$. The following are the key findings: (1) The highest protective effect of $\mathrm{H}_{2} \mathrm{~S}$ was observed with treatment at $80 \mathrm{ppm}$ applied $1.5 \mathrm{~h}$ after IRI; (2) $\mathrm{H}_{2} \mathrm{~S}$ treatment decreased the expression of the proinflammatory cytokines IL-1 $\beta$ and TNF- $\alpha$; (3) $\mathrm{H}_{2} \mathrm{~S}$ treatment reduced the expression of the pro-apoptotic Bax protein, increased the expression of the anti-apoptotic BCL-2, and attenuated NOX4 expression; (4) $\mathrm{H}_{2} \mathrm{~S}$ treatment also diminished CBS expression; (5) $\mathrm{H}_{2} \mathrm{~S}$ treatment reduced NF- $\mathrm{kB}$ phosphorylation and increased Akt phosphorylation.

The results of this study demonstrate that inhaled $\mathrm{H}_{2} \mathrm{~S}$ has protective effects after the IRI of the retina, but the extent of neuroprotection depends on the dosage and the time of application. The application of $80 \mathrm{ppm} \mathrm{H}_{2} \mathrm{~S} 1.5 \mathrm{~h}$ after IRI showed the best protection against retinal ganglion cell death. An immediate treatment with $80 \mathrm{ppm} \mathrm{H}_{2} \mathrm{~S}$ significantly reduced cell death too, although to a lesser extent than the $80 \mathrm{ppm}$ treatment at $1.5 \mathrm{~h}$. A concentration of $120 \mathrm{ppm} \mathrm{H}_{2} \mathrm{~S}$ provided a favorable effect only after a time delay of $1.5 \mathrm{~h}$, whereas treatment at $40 \mathrm{ppm}$ had no effect on ganglion cell survival after retinal IRI at any time point.

To date, studies on the neuroprotective effects of inhaled $\mathrm{H}_{2} \mathrm{~S}$ have been performed predominantly at concentrations of 40 or $80 \mathrm{ppm}$. For example, Wei et al. administered inhaled $\mathrm{H}_{2} \mathrm{~S}$ to rabbits at a concentration of $80 \mathrm{ppm}$ for $1 \mathrm{~h}$ immediately after induced cardiac arrest and resuscitation and after the return of spontaneous circulation (ROSC). They found that $\mathrm{H}_{2} \mathrm{~S}$ treatment reduced the adverse histopathological changes in the brain, improved neurological function, and improved survival in $\mathrm{H}_{2} \mathrm{~S}$-treated animals compared with a sham group [15]. Another study tested two $\mathrm{H}_{2} \mathrm{~S}$ concentrations (40 or $80 \mathrm{ppm}$ ) in rats immediately after induced cardiac arrest and subsequent ROSC. Both concentrations showed a neuroprotective effect in terms of reduced neuronal cell loss, improved neurological function, and better overall survival [16]. A series of experiments in 
rats by Wei et al. showed that middle cerebral artery occlusion for $2 \mathrm{~h}$ followed immediately by a $3 \mathrm{~h}$ treatment with $\mathrm{H}_{2} \mathrm{~S}$ at either concentration at the onset of reperfusion resulted in improved neurologic function and reduced infarct size at $24 \mathrm{~h}$ compared to the sham group. Both concentrations showed a similar protective effect. Similarly, Geng and colleagues studied the neuroprotective effect of $80 \mathrm{ppm} \mathrm{H}_{2} \mathrm{~S}$ applied with a time delay of $1 \mathrm{~h}$ after the return of spontaneous circulation (ROSC) after induced cardiac arrest and cardiopulmonary resuscitation. They also showed sufficient protection and reduced permeability of the blood-brain barrier, decreased cerebral edema, and improved neurological outcome and survival [12]. However, the neuroprotective effect of $\mathrm{H}_{2} \mathrm{~S}$ at a concentration of $120 \mathrm{ppm}$ or at other time intervals following IRI has not been studied previously.

In our study, the neuroprotective effect of $\mathrm{H}_{2} \mathrm{~S}$ was investigated for the first time in a dose- and time-dependent manner. The best effect was given with $80 \mathrm{ppm}$, either immediately after IRI, or after a time delay of $1.5 \mathrm{~h}$ from the onset of reperfusion. A concentration of $40 \mathrm{ppm}$ seemed too low to protect against retinal ganglion cell death after IRI. Similarly, a time lag of $3 \mathrm{~h}$ seemed too long to protect against an early-onset injury mechanism at all concentrations. The reason why no neuroprotective effect was observed for $120 \mathrm{ppm}$ $\mathrm{H}_{2} \mathrm{~S}$ administered immediately after the termination of ischemia is unknown. One may speculate that a toxic component of $\mathrm{H}_{2} \mathrm{~S}$ might counteract the protective effect, possibly at the mitochondrial level, but this was not investigated in detail in the present study. No further loss of vital retinal ganglion cells due to $\mathrm{H}_{2} \mathrm{~S}$ was observed in our animals.

Our investigation of the underlying neuroprotective mechanism demonstrated that $\mathrm{H}_{2} \mathrm{~S}$ treatment increased Akt phosphorylation and reduced the IRI-induced increase in NF- $\mathrm{kB}$ phosphorylation, with each response showing a dose- and time-dependent effect of $\mathrm{H}_{2} \mathrm{~S}$. Akt and the transcription factor NF- $\mathrm{kB}$ are significantly involved in anti-apoptotic and inflammatory processes in neuronal IRI [17]. Hypoxia resulting from IRI leads to the activation of Akt, which triggers effects such as pro-survival functions and the inhibition of apoptotic signaling pathways in mitochondria $[18,19]$. Intracellular signaling triggers an apoptotic stimulus that causes the oligomerization of the Bcl-2 antagonist and Bax, thereby inactivating Bcl-2. Activated Bax then alters the mitochondrial membrane potential, stimulates the release of cytochrome c, and activates caspases [20,21].

Another key regulator in neuronal ischemia is nuclear factor kappa B (NF- $\mathrm{BB})$, which, in its phosphorylated active form, regulates the expression of pro-inflammatory and proapoptotic genes [22-24]. We observed a reduced expression of the pro-inflammatory cytokines IL-1 1 and TNF- $\alpha$, and found a decreased expression of the pro-apoptotic protein $\mathrm{Bax}$ and an increased expression of the anti-apoptotic Bcl-2. The respective changes depended on the $\mathrm{H}_{2} \mathrm{~S}$ concentrations and time intervals used, with the strongest effect at $80 \mathrm{ppm}$ and a delay of $1.5 \mathrm{~h}$.

The underlying neuroprotective mechanism of inhaled $\mathrm{H}_{2} \mathrm{~S}$ after acute neuronal damage has been previously analyzed in a few studies. Our results are in accordance with the findings reported by Wei et al. [16], who showed that inhaled $\mathrm{H}_{2} \mathrm{~S}$ mediates cerebroprotective effects after induced cardiac arrest. They determined that $\mathrm{H}_{2} \mathrm{~S}$ caused a reduction in NF- $\mathrm{KB}$ phosphorylation and decreased the release of the pro-inflammatory cytokines IL- 6 and TNF- $\alpha$. Similarly, Zhang et al. demonstrated the anti-apoptotic effects of exogenously supplied $\mathrm{H}_{2} \mathrm{~S}$ in their study on traumatic brain injuries in mice. They found that $\mathrm{H}_{2} \mathrm{~S}$ applied after injury reduced caspase- 3 cleavage and increased Bcl-2 expression in injured brain tissue [25]. A neuroprotective effect of exogenous $\mathrm{H}_{2} \mathrm{~S}$ was also demonstrated in a mouse model of induced Parkinson's disease by the promotion of neurogenesis via Akt [26].

In the present study, we were able to show that inhaled $\mathrm{H}_{2} \mathrm{~S}$ inhibits the NADPH oxidase 4 (NOX4) enzyme. The complex process by which IRI leads to the death of neuronal ganglion cells involves oxidative stress and pathogenesis caused by the formation of oxygen radicals $[27,28]$. A protective, anti-oxidative effect of $\mathrm{H}_{2} \mathrm{~S}$ has previously been demonstrated in a variety of organs, including neuronal tissues such as the retina [29-32]. The production of reactive oxygen species by neutrophil granulocytes occurs via NOX4 
activity. For example, Wang and colleagues demonstrated that exogenously supplied $\mathrm{H}_{2} \mathrm{~S}$ significantly reduced cerebral NOX4 expression in a mouse model of middle cerebral artery occlusion [33].

Endogenic hydrogen sulfide is produced in many tissues and seems to play an important role in physiological and pathophysiological processes [34,35]. In the retina, $\mathrm{H}_{2} \mathrm{~S}$ is predominantly produced by CBS and cystathionine $\gamma$-lyase (CSE), which are localized in the ganglion cell layer [36]. The function of endogenous CBS in the retina is unclear at present. However, some evidence supports a role for endogenously produced $\mathrm{H}_{2} \mathrm{~S}$ in ischemic brain injury and that elevated $\mathrm{H}_{2} \mathrm{~S}$ levels contribute to poor outcomes [37]. We demonstrated that the inhalation of 120 ppm $\mathrm{H}_{2} \mathrm{~S}$ strongly reduced the expression of CBS after IRI. The lack of a protective effect strengthens the hypothesis that a certain toxic component, such as the inhibition of the respiratory chain, counteracts the $\mathrm{H}_{2} \mathrm{~S}$ effects-at least in a minor way.

\section{Materials and Methods}

\subsection{Animals}

We used adult male and female Sprague-Dawley rats (1:1male-to-female ratio, body weights of 280-350 g, Charles River, Sulzfeld, Germany) for these experiments. The animals were fed a standard diet ad libitum and kept on a light/dark cycle of $12 \mathrm{~h}$ of each. All interventions performed were in accordance with the ARRIVE guidelines for the use of animals in research and were approved a priori by the Committee for Animal Care of the University of Freiburg (approval number: 35-9185.81/G-16/46). All types of operations and manipulations were performed as previously described [38-40]. The number of animals for RGC quantification and molecular analysis was $n=8$ per group. For the analysis of the mRNA and protein expression and immunohistology, the retinal tissue was collected $24 \mathrm{~h}$ after $\mathrm{H}_{2} \mathrm{~S}$ inhalation.

\subsection{Retrograde Labeling of RGC}

Sprague-Dawley rats were anesthetized with isoflurane and placed in a stereotactic apparatus (Stoelting, Kiel, Germany). The skin over the skull was incised and retracted. For drilling three holes on each side of the Sagittal suture, the Lambda and Bregma sutures served as landmarks. Then, a total amount of $7.8 \mu \mathrm{L}$ of fluorogold (FG) (Fluorochrome, Denver, CO, USA)—dissolved in DMSO/PBS—-was injected through the drilling holes into both superior colliculi. To ensure the adequate retrograde transport of FG into the perikarya of the RGC, further experimental procedures were conducted seven days later.

\subsection{Retinal Ischemia/Reperfusion Injury and $\mathrm{H}_{2} \mathrm{~S}$ Treatment}

After randomization, rats received intraperitoneal sedation. Next, the anterior chamber of the left eye was cannulated with a 30-gauge needle connected to a reservoir containing $0.9 \% \mathrm{NaCl}$. The intraocular pressure was raised to $120 \mathrm{~mm} \mathrm{Hg}$ due to the hydrostatic pressure of the water column. The immediate onset of ocular ischemia was confirmed by the microscopical detection of interrupted retinal blood flow. After $60 \mathrm{~min}$, reperfusion was initiated by the removal of the needle tip. Failure to immediately restore retinal perfusion at the end of ischemia resulted in the exclusion of the animal, as did lens injury since it prevents RGC death and promotes axonal regeneration [41]. To evaluate the neuroprotective effect of inhaled $\mathrm{H}_{2} \mathrm{~S}$, the animals were randomized to receive either room air or $\mathrm{H}_{2} \mathrm{~S}$ at concentrations of 40,80 , or 120 ppm in $21 \%$ oxygen and the appropriate amount of nitrogen (Air Liquide, Kornwestheim, Germany) for $60 \mathrm{~min}$. Therefore, animals were placed in an airtight chamber (the dimensions of the chamber were $20 \times 35 \times 27 \mathrm{~cm}$; the flow rate was $8 \mathrm{~L} / \mathrm{min}$ initially for $10 \mathrm{~min}$, then reduced to $2 \mathrm{~L} / \mathrm{min}$ ). Treatment with hydrogen sulfide was initiated either immediately after reperfusion or with a delay of 1.5 or $3 \mathrm{~h}$. 


\subsection{RGC Quantification}

For RGC quantification, the animals were sacrificed by $\mathrm{CO}_{2}$ inhalation 7 days after ischemia. Immediately removed retinal tissue was placed in ice-cold Hank's balanced salt solution and processed further for whole-mount preparation. The retinas were carefully placed on a nitrocellulose membrane with the ganglion cell layer (GCL) on top. Subsequently, remnants of the vitreous body were removed and the retinae were fixed in $4 \%$ paraformaldehyde for $1 \mathrm{~h}$ and embedded in mounting medium (Vectashield; Axxora, Loerrach, Germany). The densities of FG-positive RGC were determined in a blinded fashion using a fluorescence microscope (AxioImager; Carl Zeiss, Jena, Germany) and the appropriate bandpass emission filter (FG: excitation/emission, 331/418 nm), as described previously $[38,39,42]$. Briefly, we photographed 3 standard rectangular areas $\left(0.200 \mathrm{~mm} \times 0.200 \mathrm{~mm}=0.04 \mathrm{~mm}^{2}\right)$ at 1,2 , and $3 \mathrm{~mm}$ from the optic disc in the central regions of each retinal quadrant. Thus, we evaluated an area of $0.48 \mathrm{~mm}^{2}$ per retina. To calculate the average RGC density in cells $/ \mathrm{mm}^{2}$, we multiplied the number of cells analyzed $/ 0.04 \mathrm{~mm}^{2}$ by 25 . Secondary fluorogold-stained-activated microglial cells (AMC) after RGC phagocytosis were identified according to morphologic criteria and excluded from the calculation. All data are presented as the mean RGC densities (cells $\left./ \mathrm{mm}^{2}\right) \pm S D$.

\subsection{Real-Time Polymerase Chain Reaction}

From retinal tissue harvested $24 \mathrm{~h}$ after ischemia, the total RNA from one-quarter of the retina was extracted using a column purification-based kit (RNeasy Micro Kit, Qiagen, Hilden, Germany) according to the manufacturer's instructions. Reverse transcription was performed with 50 ng of total RNA using random primers (High Capacity cDNA Reverse Transcription Kit, Thermo Fisher Scientific, Waltham, MA, USA). Real-time polymerase chain reactions (RT-PCR) were done with a TaqMan ${ }^{\circledR}$ probe-based detection kit (TaqMan ${ }^{\circledR}$ PCR Universal Master Mix, Thermo Fisher Scientific, Waltham, MA, USA). The following primers were used: Bax \#Rn01480161_g1, BCL-2 \#Rn99999125_m1, IL-1ß \#Rn00580432_m1, TNF- $\alpha$ \#Rn01525859_g1, NOX4 \#Rn00585380_m1, CBS \#Rn00650948_m1 (all from Thermo Fisher Scientific, Waltham, MA, USA). The PCR assays were then performed on an RT-PCR System (StepOnePlus ${ }^{\circledR}$, Thermo Fisher Scientific, Waltham, MA, USA) with the following cycling conditions: $95^{\circ} \mathrm{C}$ for $10 \mathrm{~min}, 40$ cycles of $95^{\circ} \mathrm{C}$ for $10 \mathrm{~s}$, and $60{ }^{\circ} \mathrm{C}$ for $1 \mathrm{~min}$. Reaction specificity was confirmed by running the appropriate negative controls. The cycle threshold (CT) values for each gene of interest were normalized to the corresponding CT values for glyceraldehyde 3-phosphate dehydrogenase (GAPDH) $(\triangle \mathrm{CT})$. The relative gene expression in IR injured retinal tissue, either with the inhalation of hydrogen sulfide or room air, was calculated in relation to the corresponding gene expression in the non-injured retinal tissue of each individual animal $(\Delta \Delta \mathrm{CT})$.

\subsection{Immunohistochemical Staining}

For this analysis, eyes were enucleated $24 \mathrm{~h}$ after ischemia, immediately placed in $4 \%$ paraformaldehyde for $1 \mathrm{~h}$ at $4{ }^{\circ} \mathrm{C}$. After washing in Dulbecco's phosphate-buffered saline (D-PBS) before and after post-fixation in $20 \%$ sucrose for $4 \mathrm{~h}$ at room temperature, the eyes were embedded in Tissue-Tek (Sakura-Finetek, Torrance, CA, USA) and frozen in liquid nitrogen. Frozen sections $(10 \mu \mathrm{m})$ were cut through the middle third of the eye and collected on gelatinized slides. Immunohistochemistry was performed according to standardized protocols [38]. A polyclonal Rabbit anti-TNF-alpha antibody was used (\#ab6671, dilution 1:500, Abcam, Cambridge, UK) and detected with a corresponding fluorophore-conjugated secondary antibody (Alexa Fluor 647, mouse anti-rabbit, dilution 1:1000, Jackson ImmunoResearch Europe, Newmarket, UK). Retinal cell nuclei were stained by adding $4^{\prime}, 6$-diamino-2-phenylindole dihydrochloride hydrate (DAPI; Sigma) to Mowiol mounting medium. The slides were examined under a fluorescence microscope (Axiophot, Carl Zeiss, Jena, Germany). 


\subsection{ELISA}

Serum samples were analyzed using a commercial kit for TNF- $\alpha$ (\#RTA00, R\&D Systems, Minneapolis, MN, USA) according to the manufacturer's instructions. OD was analyzed at $450 \mathrm{~nm}$ on a microplate reader (Tecan ${ }^{\circledR}$, Männedorf, Switzerland).

\subsection{Western Blot Analysis}

After $24 \mathrm{~h}$ of ischemia, retinal tissue was collected for protein expression analysis. The total protein from three-quarters of the retina was extracted and processed for Western blot, as previously described [42]. The membranes were blocked with 5\% skim milk in Tween20/PBS and incubated in the recommended dilution of protein-specific antibody (p-NF-kB\#3033, p-Akt\#9271, Cell Signaling Technology, Danvers, MA, USA) overnight at $4{ }^{\circ} \mathrm{C}$. After incubation with a horseradish peroxidase-conjugated anti-rabbit secondary antibody (GE Healthcare, Freiburg, Germany), the proteins were visualized using enhanced chemiluminescence Western blotting detection reagent (Western Lightning plus enhanced chemiluminescence, \#NEL104001EA, PerkinElmer, Waltham, MA, USA) following the manufacturer's instructions. For normalization, the blots were re-probed with total NF- $\mathrm{kB}$ (\#8242, Cell Signaling) and total Akt (\#9272, Cell Signaling). Relative changes in protein expression in IRI retinas after either hydrogen sulfide or room air inhalation were calculated relative to corresponding nonischemic retinas. Recordings and densitometric analysis were performed using Fusion Fx ${ }^{\circledR}$ (Vilber, Collegién, France).

\subsection{Statistical Analysis}

A computerized statistics program (SigmaPlot Version 11.0, Systat Software Inc., San Jose, CA, USA) was used to evaluate the data. After checking the normal distribution of the data, the results were presented as mean values (SD). Between-group comparisons were performed with one-way ANOVA using the post hoc Holm-Sidak test and KruskalWallis test for data with missing normal distribution. Statistical significance was assumed at $p<0.05$.

\section{Conclusions}

We demonstrated that inhaled hydrogen sulfide protects retinal ganglion cells against ischemia-reperfusion injury. The effect depends on the time of application as well as on the administered dose. $\mathrm{H}_{2} \mathrm{~S}$ mediates part of its effect via anti-oxidative, anti-inflammatory, and anti-apoptotic properties, while its molecular mechanism may be strengthened by an NF- $\mathrm{kB}$ and Akt dependent pathway.

Author Contributions: Conceptualization, W.B., U.G. and F.U.; data curation, S.S., M.G. and F.U.; formal analysis, F.U.; investigation, S.S., M.G. and F.U.; methodology, S.S., G.S., and F.U.; project administration, S.S., H.B., W.L. and U.G.; resources, H.B., G.S. and W.L.; software, G.S.; supervision, J.W., H.B., and W.L.; visualization, M.G., and G.S.; writing-original draft, S.S., U.G. and F.U.; writing-review and editing, M.G., W.B., J.W., G.S. and U.G. All authors have read and agreed to the published version of the manuscript.

Funding: This work was financially supported by the Department of Anesthesiology and Critical Care, Medical Center-University of Freiburg, Germany. The article processing charge was funded by the Baden-Wuerttemberg Ministry of Science, Research and Art and the University of Freiburg in the funding programme Open Access Publishing.

Institutional Review Board Statement: All procedures involving animals concurred with the statement of the Association for Research in Vision and Ophthalmology for the use of animals in research in accordance with the ARRIVE guidelines and were approved a priori by the Committee of Animal Care of the University of Freiburg (Permit No: 35-9185.81/G-16/46).

Informed Consent Statement: Not applicable. 
Data Availability Statement: All data generated or analyzed in this study are included in this published article.

Conflicts of Interest: There are no competing conflict of interest.

\section{References}

1. Datta, A.; Sarmah, D.; Mounica, L.; Kaur, H.; Kesharwani, R.; Verma, G.; Veeresh, P.; Kotian, V.; Kalia, K.; Borah, A.; et al. Cell Death Pathways in Ischemic Stroke and Targeted Pharmacotherapy. Transl. Stroke Res. 2020, 11, 1185-1202. [CrossRef]

2. Kabil, O.; Banerjee, R. Enzymology of H2S biogenesis, decay and signaling. Antioxid. Redox Signal. 2014, 20, 770-782. [CrossRef]

3. Lee, M.; Schwab, C.; Yu, S.; McGeer, E.; McGeer, P.L. Astrocytes produce the antiinflammatory and neuroprotective agent hydrogen sulfide. Neurobiol. Aging 2009, 30, 1523-1534. [CrossRef] [PubMed]

4. Ishigami, M.; Hiraki, K.; Umemura, K.; Ogasawara, Y.; Ishii, K.; Kimura, H. A source of hydrogen sulfide and a mechanism of its release in the brain. Antioxid. Redox Signal. 2009, 11, 205-214. [CrossRef]

5. Ren, C.; Du, A.; Li, D.; Sui, J.; Mayhan, W.G.; Zhao, H. Dynamic change of hydrogen sulfide during global cerebral ischemiareperfusion and its effect in rats. Brain Res. 2010, 1345, 197-205. [CrossRef]

6. Tang, G.; Wu, L.; Liang, W.; Wang, R. Direct stimulation of K(ATP) channels by exogenous and endogenous hydrogen sulfide in vascular smooth muscle cells. Mol. Pharmacol. 2005, 68, 1757-1764. [CrossRef] [PubMed]

7. Hosoki, R.; Matsuki, N.; Kimura, H. The possible role of hydrogen sulfide as an endogenous smooth muscle relaxant in synergy with nitric oxide. Biochem. Biophys. Res. Commun. 1997, 237, 527-531. [CrossRef] [PubMed]

8. Ohsawa, I.; Ishikawa, M.; Takahashi, K.; Watanabe, M.; Nishimaki, K.; Yamagata, K.; Katsura, K.; Katayama, Y.; Asoh, S.; Ohta, S. Hydrogen acts as a therapeutic antioxidant by selectively reducing cytotoxic oxygen radicals. Nat. Med. 2007, 13, 688-694. [CrossRef]

9. Wang, J.F.; Li, Y.; Song, J.N.; Pang, H.G. Role of hydrogen sulfide in secondary neuronal injury. Neurochem. Int. 2014, 64, 37-47. [CrossRef]

10. Sen, N.; Paul, B.D.; Gadalla, M.M.; Mustafa, A.K.; Sen, T.; Xu, R.; Kim, S.; Snyder, S.H. Hydrogen sulfide-linked sulfhydration of NF-кB mediates its antiapoptotic actions. Mol. Cell 2012, 45, 13-24. [CrossRef]

11. Nicholls, P.; Marshall, D.C.; Cooper, C.E.; Wilson, M.T. Sulfide inhibition of and metabolism by cytochrome c oxidase. Biochem. Soc. Trans. 2013, 41, 1312-1316. [CrossRef]

12. Geng, Y.; Li, E.; Mu, Q.; Zhang, Y.; Wei, X.; Li, H.; Cheng, L.; Zhang, B. Hydrogen sulfide inhalation decreases early bloodbrain barrier permeability and brain edema induced by cardiac arrest and resuscitation. J. Cereb. Blood Flow Metab. 2015, 35, 494-500. [CrossRef]

13. Li, H.; Zhu, L.; Feng, J.; Hu, X.; Li, C.; Zhang, B. Hydrogen Sulfide Decreases Blood-Brain Barrier Damage via Regulating Protein Kinase C and Tight Junction After Cardiac Arrest in Rats. Cell. Physiol. Biochem. 2018, 47, 994-1006. [CrossRef]

14. Biermann, J.; Lagrèze, W.A.; Schallner, N.; Schwer, C.I.; Goebel, U. Inhalative preconditioning with hydrogen sulfide attenuated apoptosis after retinal ischemia/reperfusion injury. Mol. Vis. 2011, 17, 1275-1286. [PubMed]

15. Wei, X.; Duan, L.; Bai, L.; Tian, M.; Li, W.; Zhang, B. Effects of exogenous hydrogen sulfide on brain metabolism and early neurological function in rabbits after cardiac arrest. Intensive Care Med. 2012, 38, 1877-1885. [CrossRef] [PubMed]

16. Wei, X.; Zhang, B.; Zhang, Y.; Li, H.; Cheng, L.; Zhao, X.; Yin, J.; Wang, G. Hydrogen Sulfide Inhalation Improves Neurological Outcome via NF-kB-Mediated Inflammatory Pathway in a Rat Model of Cardiac Arrest and Resuscitation. Cell. Physiol. Biochem. 2015, 36, 1527-1538. [CrossRef] [PubMed]

17. Zhao, E.Y.; Efendizade, A.; Cai, L.; Ding, Y. The role of Akt (protein kinase B) and protein kinase C in ischemia-reperfusion injury. Neurol. Res. 2016, 38, 301-308. [CrossRef] [PubMed]

18. Kim, A.H.; Khursigara, G.; Sun, X.; Franke, T.F.; Chao, M.V. Akt phosphorylates and negatively regulates apoptosis signalregulating kinase 1. Mol. Cell. Biol. 2001, 21, 893-901. [CrossRef] [PubMed]

19. Harada, N.; Hatano, E.; Koizumi, N.; Nitta, T.; Yoshida, M.; Yamamoto, N.; Brenner, D.A.; Yamaoka, Y. Akt activation protects rat liver from ischemia/reperfusion injury. J. Surg. Res. 2004, 121, 159-170. [CrossRef]

20. Chipuk, J.E.; Moldoveanu, T.; Llambi, F.; Parsons, M.J.; Green, D.R. The BCL-2 family reunion. Mol. Cell 2010, 37, 299-310. [CrossRef]

21. Levkovitch-Verbin, H. Retinal ganglion cell apoptotic pathway in glaucoma: Initiating and downstream mechanisms. Prog. Brain Res. 2015, 220, 37-57. [PubMed]

22. Mattson, M.P. Neuroprotective signal transduction: Relevance to stroke. Neurosci. Biobehav. Rev. 1997, 21, 193-206. [CrossRef]

23. Kaltschmidt, B.; Widera, D.; Kaltschmidt, C. Signaling via NF-kappaB in the nervous system. Biochim. Biophys. Acta Mol. Cell Res. 2005, 1745, 287-299. [CrossRef] [PubMed]

24. Ridder, D.A.; Schwaninger, M. NF-kappaB signaling in cerebral ischemia. Neuroscience 2009, 158, 995-1006. [CrossRef]

25. Zhang, M.; Shan, H.; Chang, P.; Wang, T.; Dong, W.; Chen, X.; Tao, L. Hydrogen sulfide offers neuroprotection on traumatic brain injury in parallel with reduced apoptosis and autophagy in mice. PLoS ONE 2014, 9, e87241. [CrossRef]

26. Wang, M.; Tang, J.J.; Wang, L.X.; Yu, J.; Zhang, L.; Qiao, C. Hydrogen sulfide enhances adult neurogenesis in a mouse model of Parkinson's disease. Neural Regen. Res. 2021, 16, 1353-1358.

27. Allen, C.L.; Bayraktutan, U. Oxidative stress and its role in the pathogenesis of ischaemic stroke. Int. J. Stroke 2009, 4, 461-470. [CrossRef] [PubMed] 
28. Kishimoto, M.; Suenaga, J.; Takase, H.; Araki, K.; Yao, T.; Fujimura, T.; Murayama, K.; Okumura, K.; Ueno, R.; Shimizu, N.; et al. Oxidative stress-responsive apoptosis inducing protein (ORAIP) plays a critical role in cerebral ischemia/reperfusion injury. Sci. Rep. 2019, 9, 13512. [CrossRef]

29. Xie, Z.Z.; Liu, Y.; Bian, J.S. Hydrogen Sulfide and Cellular Redox Homeostasis. Oxid. Med. Cell. Longev. 2016, 2016, 6043038. [CrossRef]

30. Liu, H.; Anders, F.; Thanos, S.; Mann, C.; Liu, A.; Grus, F.H.; Pfeiffer, N.; Prokosch-Willing, V. Hydrogen Sulfide Protects Retinal Ganglion Cells Against Glaucomatous Injury In Vitro and In Vivo. Investig. Ophthalmol. Vis. Sci. 2017, 58, 5129-5141. [CrossRef] [PubMed]

31. Huanga, S.; Huang, P.; Lin, Z.; Liu, X.; Xu, X.; Guo, L.; Shen, X.; Li, C.; Zhong, Y. Hydrogen sulfide supplement attenuates the apoptosis of retinal ganglion cells in experimental glaucoma. Exp. Eye Res. 2018, 168, 33-48. [CrossRef]

32. Huang, S.; Huang, P.; Yu, H.; Lin, Z.; Liu, X.; Shen, X.; Guo, L.; Zhong, Y. Extracellular Signal-Regulated Kinase $1 / 2$ Pathway Is Insufficiently Involved in the Neuroprotective Effect by Hydrogen Sulfide Supplement in Experimental Glaucoma. Investig. Ophthalmol. Vis. Sci. 2019, 60, 4346-4359. [CrossRef]

33. Wang, Y.; Jia, J.; Ao, G.; Hu, L.; Liu, H.; Xiao, Y.; Du, H.; Alkayed, N.J.; Liu, C.; Cheng, J. Hydrogen sulfide protects blood-brain barrier integrity following cerebral ischemia. J. Neurochem. 2014, 129, 827-838. [CrossRef]

34. Kimura, H. Production and physiological effects of hydrogen sulfide. Antioxid. Redox Signal. 2014, 20, 783-793. [CrossRef]

35. Zhang, M.; Wu, X.; Xu, Y.; He, M.; Yang, J.; Li, J.; Li, Y.; Ao, G.; Cheng, J.; Jia, J. The cystathionine $\beta$-synthase/hydrogen sulfide pathway contributes to microglia-mediated neuroinflammation following cerebral ischemia. Brain Behav. Immun. 2017, 66, 332-346. [CrossRef] [PubMed]

36. Takır, S.; Semiz, A.T.; Doğan, B.S.U. Hydrogen sulfide is synthesized endogenously in both retinal artery and retina mostly via CSE. Exp. Eye Res. 2021, 204, 108443. [CrossRef] [PubMed]

37. Wong, P.T.; Qu, K.; Chimon, G.N.; Seah, A.B.; Chang, H.M.; Wong, M.C.; Ng, Y.K.; Rumpel, H.; Halliwell, B.; Chen, C.P. High plasma cyst(e)ine level may indicate poor clinical outcome in patients with acute stroke: Possible involvement of hydrogen sulfide. J. Neuropathol. Exp. Neurol. 2006, 65, 109-115. [CrossRef] [PubMed]

38. Biermann, J.; Lagrèze, W.A.; Dimitriu, C.; Stoykow, C.; Goebel, U. Preconditioning with inhalative carbon monoxide protects rat retinal ganglion cells from ischemia/reperfusion injury. Investig. Ophthalmol. Vis. Sci. 2010, 51, 3784-3791. [CrossRef] [PubMed]

39. Schallner, N.; Fuchs, M.; Schwer, C.I.; Loop, T.; Buerkle, H.; Lagrèze, W.A.; van Oterendorp, C.; Biermann, J.; Goebel, U. Postconditioning with inhaled carbon monoxide counteracts apoptosis and neuroinflammation in the ischemic rat retina. $P L O S$ ONE 2012, 7, e46479. [CrossRef]

40. Fischer, D.; Pavlidis, M.; Thanos, S. Cataractogenic lens injury prevents traumatic ganglion cell death and promotes axonal regeneration both in vivo and in culture. Investig. Ophthalmol. Vis. Sci. 2000, 41, 3943-3954.

41. Ulbrich, F.; Lerach, T.; Biermann, J.; Kaufmann, K.B.; Lagreze, W.A.; Buerkle, H.; Loop, T.; Goebel, U. Argon mediates protection by Interleukin-8 suppression via a TLR2/TLR4/STAT3/NF-kappaB pathway in a model of apoptosis in neuroblastoma cells in-vitro and following ischemia-reperfusion injury in rat retina in-vivo. J. Neurochem. 2016, 138, 859-873. [CrossRef] [PubMed]

42. Ulbrich, F.; Kaufmann, K.B.; Coburn, M.; Lagrèze, W.A.; Roesslein, M.; Biermann, J.; Buerkle, H.; Loop, T.; Goebel, U. Neuroprotective effects of Argon are mediated via an ERK-1/2 dependent regulation of heme-oxygenase-1 in retinal ganglion cells. J. Neurochem. 2015, 134, 712-727. [CrossRef] [PubMed] 